\title{
Synthesis of C2 Substituted Benzothiophenes via an Interrupted Pummerer/[3,3]-Sigmatropic/1,2-Migration Cascade of Benzothiophene S-Oxides
}

DOI:

10.1002/ange.201801982

\section{Document Version}

Accepted author manuscript

Link to publication record in Manchester Research Explorer

Citation for published version (APA):

He, Z., Shrives, H., Fernandez-Salas, J. A., Abengozar, A., Neufeld, J., Yang, K., Pulis, A., \& Procter, D. (2018). Synthesis of C2 Substituted Benzothiophenes via an Interrupted Pummerer/[3,3]-Sigmatropic/1,2-Migration Cascade of Benzothiophene S-Oxides. Angewandte Chemie. https://doi.org/10.1002/ange.201801982

\section{Published in:}

Angewandte Chemie

\section{Citing this paper}

Please note that where the full-text provided on Manchester Research Explorer is the Author Accepted Manuscript or Proof version this may differ from the final Published version. If citing, it is advised that you check and use the publisher's definitive version.

\section{General rights}

Copyright and moral rights for the publications made accessible in the Research Explorer are retained by the authors and/or other copyright owners and it is a condition of accessing publications that users recognise and abide by the legal requirements associated with these rights.

\section{Takedown policy}

If you believe that this document breaches copyright please refer to the University of Manchester's Takedown Procedures [http://man.ac.uk/04Y6Bo] or contact uml.scholarlycommunications@manchester.ac.uk providing relevant details, so we can investigate your claim.

\section{OPEN ACCESS}




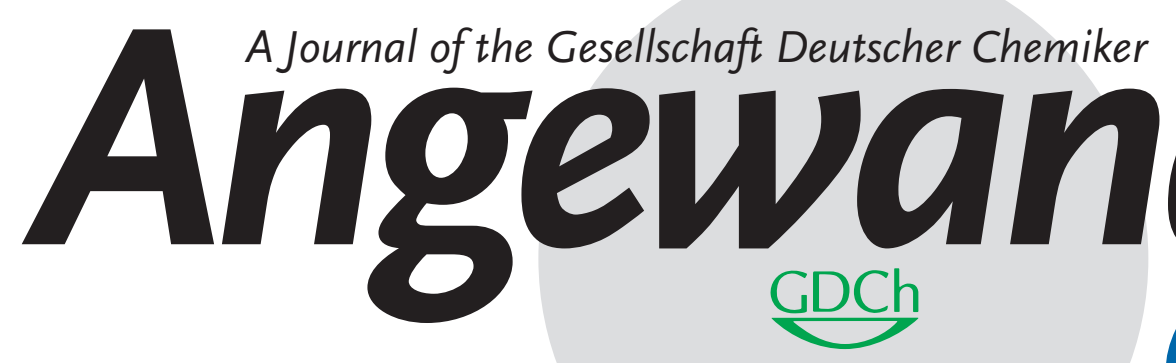

International Edition

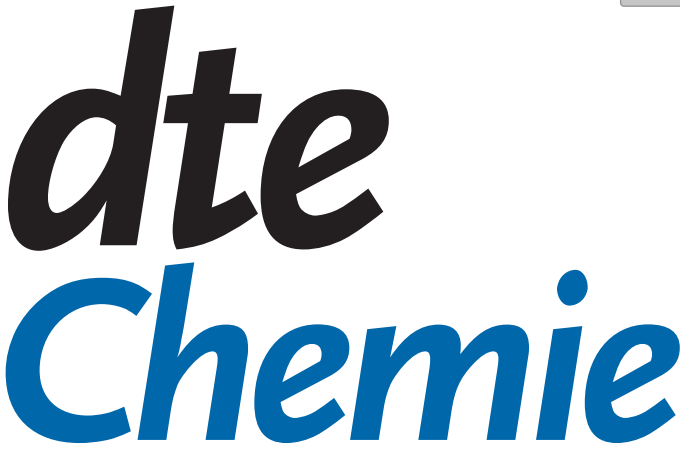

www.angewandte.org

\section{Accepted Article}

Title: Synthesis of C2 Substituted Benzothiophenes via an Interrupted Pummerer/[3,3]-Sigmatropic/1,2-Migration Cascade of Benzothiophene S-Oxides

Authors: Zhen He, Harry Shrives, José A Fernández-Salas, Alberto Abengózar, Jessica Neufeld, Kevin Yang, Alex P Pulis, and David John Procter

This manuscript has been accepted after peer review and appears as an Accepted Article online prior to editing, proofing, and formal publication of the final Version of Record (VoR). This work is currently citable by using the Digital Object Identifier (DOI) given below. The VoR will be published online in Early View as soon as possible and may be different to this Accepted Article as a result of editing. Readers should obtain the VoR from the journal website shown below when it is published to ensure accuracy of information. The authors are responsible for the content of this Accepted Article.

To be cited as: Angew. Chem. Int. Ed. 10.1002/anie.201801982

Angew. Chem. 10.1002/ange.201801982

Link to VoR: http://dx.doi.org/10.1002/anie.201801982

http://dx.doi.org/10.1002/ange.201801982 


\title{
Synthesis of C2 Substituted Benzothiophenes via an Interrupted Pummerer/[3,3]-Sigmatropic/1,2-Migration Cascade of Benzothiophene S-Oxides
}

\author{
Zhen He, Harry J. Shrives, José A. Fernández-Salas, Alberto Abengózar, Jessica Neufeld, Kevin Yang,
} Alexander P. Pulis and David J. Procter*

\begin{abstract}
Functionalized benzothiophenes are important scaffolds found in molecules with wide ranging biological activity and in organic materials. We describe an efficient, metal-free synthesis of C2 arylated, allylated and propargylated benzothiophenes. The reaction utilizes synthetically unexplored yet readily accessible benzothiophene $S$-oxides and phenols, allyl- or propargyl silanes in a unique cascade sequence. An interrupted Pummerer reaction between benzothiophene $S$-oxides and the coupling partners yields sulfonium salts that lack aromaticity and therefore allow facile [3,3]sigmatropic rearrangement. The subsequently generated benzothiophenium salts undergo a previously unexplored 1,2migration to access $\mathrm{C} 2$ functionalized benzothiophenes.
\end{abstract}

Functionalized benzothiophenes are important heterocycles and are commonly found in molecules with wide ranging biological activity, ${ }^{[1,2]}$ and are components in many organic functional materials (Scheme 1A). ${ }^{[3]}$

Substituted benzothiophenes can be constructed by annulation of either ring or by functionalization of the benzothiophene core. ${ }^{[4]}$ An attractive strategy for the preparation of $\mathrm{C} 2$ substituted benzothiophenes involves functionalization of $\mathrm{C}-\mathrm{H}$ bonds found in the parent heterocyclic motif. ${ }^{[5]}$ Due to the increased acidity of the $\mathrm{C} 2 \mathrm{C}-\mathrm{H}$ bond, classical methods for introducing carbon substituents at the expense of $\mathrm{C}-\mathrm{H}$ bonds at $\mathrm{C} 2$ of benzothiophenes require stoichiometric metallation and such processes employ highly basic organometallic reagents. ${ }^{[6]}$ Alternatively, Friedel-Crafts alkylation processes can be used but often give mixtures of $\mathrm{C} 2$ and $\mathrm{C} 3$ substituted products. ${ }^{[7]}$ In addition to these limitations, both strategies are restricted to the use of electrophilic coupling partners.

Transition metals are able to mediate regioselective $\mathrm{C}-\mathrm{H}$ arylation at the $\mathrm{C} 2$ position of benzothiophenes. ${ }^{[8]}$ However, transition metal catalyzed $\mathrm{C} 2 \mathrm{C}-\mathrm{H}$ alkylation of benzothiophenes is considerably more challenging as it requires high temperatures and is only reported in isolated cases. ${ }^{[9]}$ Furthermore, metal contamination remains an issue when certain transition metals are used, especially when the products are destined for human consumption ${ }^{[10]}$ or when trace metal contamination can affect product performance, such as in organic electronics. ${ }^{[11]}$ Thus, a method that selectively introduces a carbon substituent at $\mathrm{C} 2$ in place of the $\mathrm{C}-\mathrm{H}$ bonds of benzothiophenes under transition metal-free conditions is an attractive proposition

[] Dr. Z. He, H. J. Shrives, Dr. J. A. Fernández-Salas, A. Abengózar, J. Neufeld, Kevin Yang, Dr. A. P. Pulis and Prof. Dr. D. J. Procter School of Chemistry, University of Manchester Oxford Rd, Manchester, M13 9PL (UK)

E-mail: david.j.procter@manchester.ac.uk

Supporting information for this article is given via a link at the end of the document.

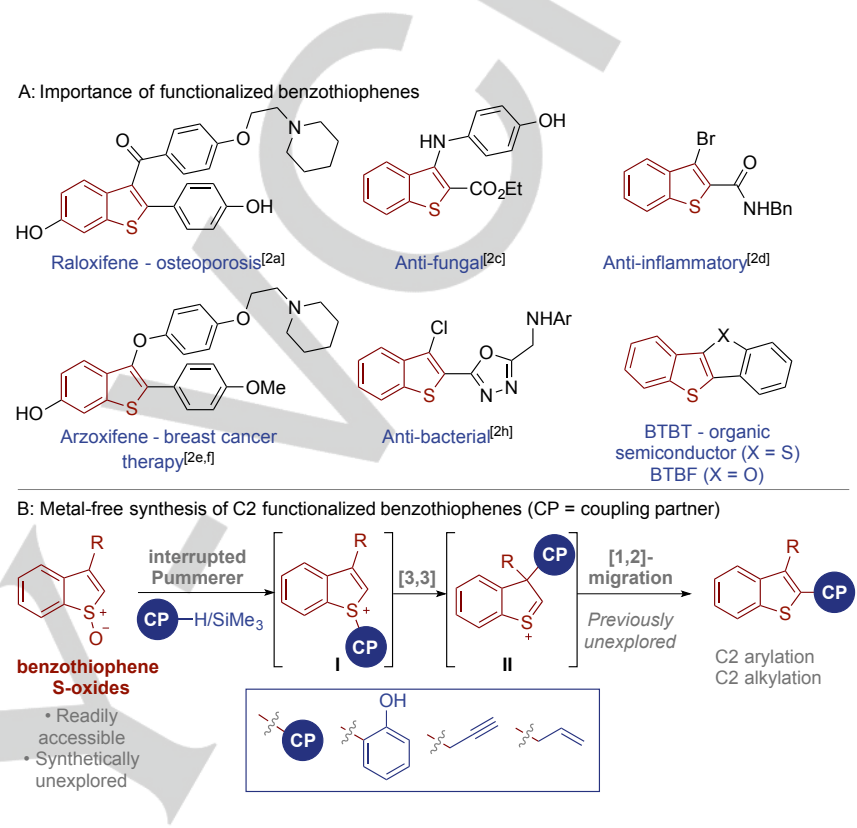

Scheme 1. Importance of functionalized benzothiophenes and our metal-free strategy for their synthesis.

The groups of Yorimitsu, ${ }^{[12]}$ Maulide ${ }^{[13]}$ Procter $^{[14]}$ and others ${ }^{[15]}$ have contributed to a growing body of work describing the use of sulfonium intermediates ${ }^{[16-18]}$ in the ortho $\mathrm{C}-\mathrm{H}$ alkylation and arylation of aromatic sulfoxides. We have recently reported the use of benzothiophene $S$-oxides in the synthesis of C3-arylated and -alkylated benzothiophenes via an interrupted Pummerer ${ }^{[19]} /[3,3]$-sigmatropic rearrangement ${ }^{[16,20]}$ cascade. ${ }^{[21]}$ Herein we report a metal-free synthesis of $\mathrm{C} 2$ functionalized benzothiophenes (Scheme 1B). Using readily available, yet synthetically underutilized benzothiophene $S$-oxides as novel starting materials, we engage phenol, and allyl and propargyl silanes in a strategy that delivers C2 substituted benzothiophenes in a regioselective manner under mild conditions. The $\mathrm{C} 2 \mathrm{C}-\mathrm{H}$ alkylation and arylation processes operate via an interrupted Pummerer/[3,3]-sigmatropic rearrangement sequence to generate 3,3-disubstituted benzothiophenium salts II, that subsequently undergo a previously unexplored 1,2-migration.

In comparison to regular aromatic sulfoxides, benzothiophene S-oxides (1) have received little attention as synthetic intermediates. Until recently, their use in Pummerertype processes had not been described ${ }^{[21,22]}$ and reports of their reactivity was limited to cycloaddition and $S_{N} A r$ type processes, ${ }^{[23]}$ even though benzothiophene $S$-oxides are readily prepared from the parent benzothiophene by oxidation with $\mathrm{H}_{2} \mathrm{O}_{2}$ and TFA, ${ }^{[24]}$ or with $m \mathrm{CPBA}$ and $\mathrm{BF}_{3} \cdot \mathrm{OEt}_{2},{ }^{[25]}$ without over oxidation. 
We have shown that benzothiophene S-oxides 1 serve as precursors to benzothiophenium salts (cf. I) via an interrupted Pummerer reaction with suitable nucleophilic coupling partners. ${ }^{[1]}$ We proposed that salts I would be predisposed to facile [3,3]-sigmatropic rearrangement, and that the 3,3disubstituted benzothiophenium intermediates (cf. II) would then be able to undergo 1,2-migration and thus deliver C2 functionalized products. However, questions remained as to whether an existing substituent at C3 would affect the [3,3]sigmatropic rearrangement, the key process that delivers the coupling partner to the benzothiophene scaffold, and whether selective migration of the coupling partner could be achieved. Notably, while 1,2-migrations of the related 3,3-disubstituted indolenines are well established, ${ }^{[26]}$ the analogous reaction of 3,3-disubstituted benzothiopheniums (cf. II) has not been previously explored. ${ }^{[27]}$

We began by investigating the coupling between C3 methyl benzothiophene $S$-oxide 1a and $p$-cresol (2a) (Scheme 2A). Upon treating $1 \mathrm{a}$ and $\mathbf{2 a}$ with TFAA in $\mathrm{CH}_{2} \mathrm{Cl}_{2}$, isolable thioacetal 3a was formed in $75 \%$ yield, indicating that the $[3,3]$-sigmatropic rearrangement occurs efficiently despite the presence of a $\mathrm{C} 3$ substituent. Pleasingly, reaction of 3,3-disubstituted thioacetal 3a with catalytic $\mathrm{BF}_{3} \cdot \mathrm{OEt}_{2}$ induced opening of the thioacetal and selective 1,2-migration of the aryl group to form the C2 functionalized benzothiophene $4 a^{[28]}$

The coupling of $1 \mathbf{a}$ and $p$-cresol (2a) could be carried out in a one-pot procedure, leading to $\mathbf{4 a}$ in $80 \%$ isolated yield (Scheme 2B). The scope of the $\mathrm{C} 2 \mathrm{C}-\mathrm{H}$ arylation was surveyed by varying the phenol and benzothiophene $S$-oxide coupling partners in the one-pot process. Functional groups, including bromo $(\mathbf{4 b}, \mathbf{f}, \mathbf{i})$, trifluoromethyl $(\mathbf{4 c})$, keto $(\mathbf{4 d})$, nitro $(\mathbf{4 e}, \mathbf{4 g})$, and amido (4h) were well tolerated in the phenol coupling partner. In the coupling of 3 -bromophenol (formation of $4 \mathbf{i}$ ), complete selectivity for the least hindered ortho position was observed. Naphthalen-1-ol and naphthalen-2-ol coupling partners were also amenable to the process $(\mathbf{4 k}, \mathbf{I})$, and the hindered biaryls $4 \mathbf{j}$ and $\mathbf{4 k}$ were formed in good yields. The regioselectivity of the metal-free C2-arylation was confirmed by NMR studies and by $\mathrm{X}$-ray crystallographic analysis of $\mathbf{4 d}$ and $\mathbf{4} \mathbf{q}^{\text {, }}$. ${ }^{29]}$

A variety of benzothiophene $S$-oxides 1 was also evaluated in the C2 arylation and we found that the reaction embraces many substitution patterns and functional groups $(4 m-a c)$. Alkyl $(\mathbf{4 m}, \mathbf{r}, \mathbf{s})$, bromo $(\mathbf{4 n})$, propargyl $(40)$, allyl $(\mathbf{4 p}, \mathbf{q})$, and aryl $(\mathbf{4 v - z})$ proved to be compatible C3 substituents. The coupling of C3 allyl benzothiophene $S$-oxide with phenol, gave $\mathbf{4 q}$ selectively under the standard conditions, whereas employing stoichiometric $\mathrm{BF}_{3} \cdot \mathrm{OEt}_{2}$ and heating allowed for in situ cyclization of the phenolic oxygen onto the alkene to form the benzoxepine 4q'.

Noteworthy is the efficient synthesis of the C3 bromo- (4n), and C3 oxygenated- C2 arylated products (4aa-ac) that bear the key structural features of some biologically active benzothiophenes (see Scheme 1). The analogous C3 nitrogen substituted benzothiophene $S$-oxides were also successfully arylated, albeit in lower isolated yields $(\mathbf{4 t}, \mathbf{u})$.

Crucially, in all cases the phenol coupling partner exclusively migrated from $\mathrm{C} 3$ to $\mathrm{C} 2$ in the 3,3-disubstituted benzothiophenium intermediate (cf. II) formed after [3,3]sigmatropic rearrangement, even when the existing $\mathrm{C} 3$ substituent had a comparable migratory aptitude: For example, in $4 x$ where $\mathrm{C} 3$ bears a para-methoxyphenyl group (vide infra).

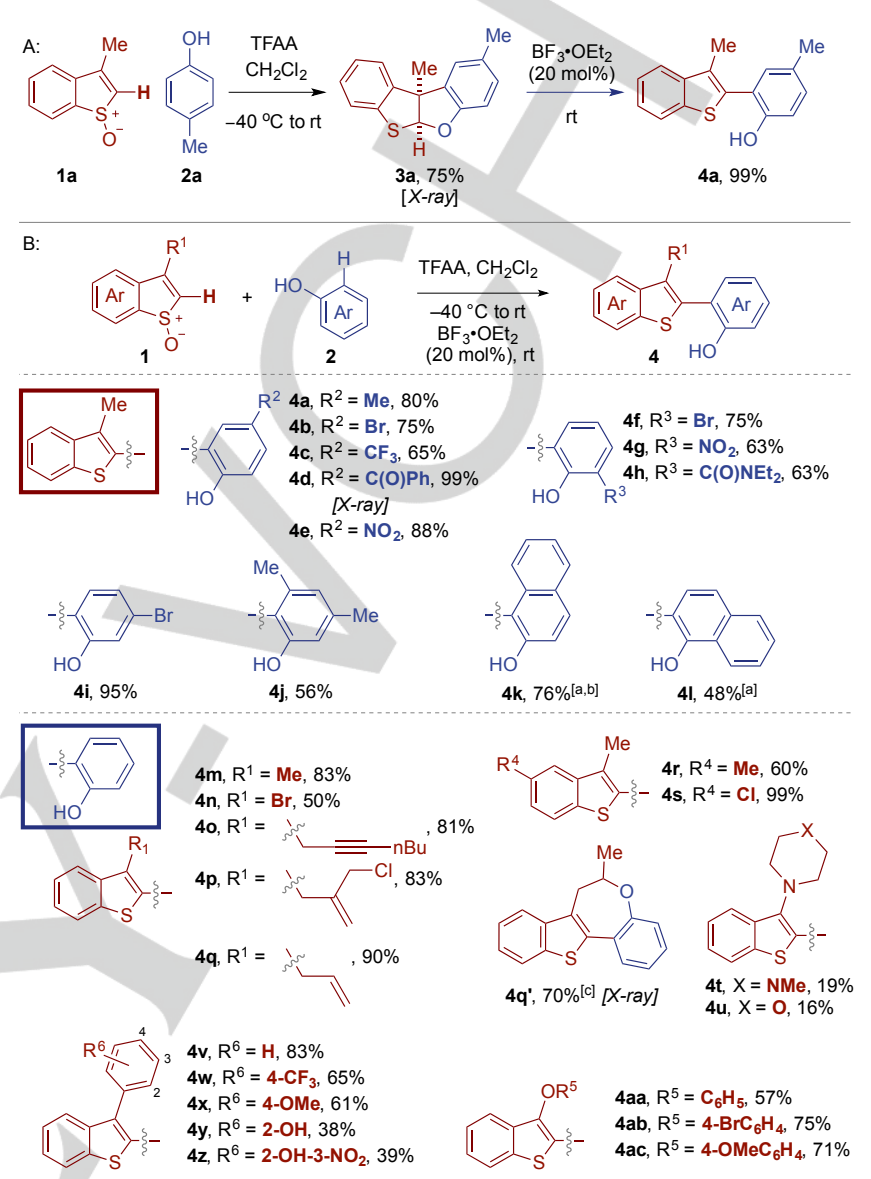

Scheme 2. Development of the metal-free $\mathrm{C} 2$ arylation of benzothiophene $S$ oxide (A) and scope (B). Conditions: 1 (0.1 mmol), $\mathrm{CH}_{2} \mathrm{Cl}_{2}(1.0 \mathrm{ml}),-40{ }^{\circ} \mathrm{C}$; TFAA (0.15 mmol); $2(0.15 \mathrm{mmol}), 15 \mathrm{~min}$; rt, overnight; $\mathrm{BF}_{3} \cdot \mathrm{OEt}_{2}(0.02 \mathrm{mmol})$, rt, $1 \mathrm{~h}$. Isolated yields. [a] THF used instead of $\mathrm{CH}_{2} \mathrm{Cl}_{2}$. [b] Heated at $45{ }^{\circ} \mathrm{C}$ after $\mathrm{BF}_{3} \cdot \mathrm{OEt}_{2}$ added. [c] Heated at $60{ }^{\circ} \mathrm{C}$ after $\mathrm{BF}_{3} \cdot \mathrm{OEt}_{2}$ added.
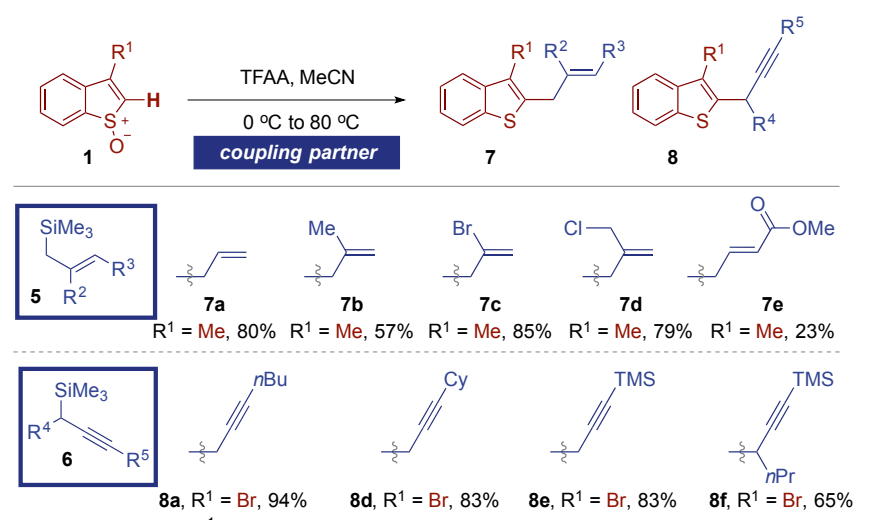
8 b, $R^{1}=\mathrm{Me}, 87 \%$ $8 \mathrm{c}$,<smiles>[R17]=CCC#CCCCC</smiles>

Scheme 3. Scope of the metal-free $\mathrm{C} 2$ alkylation of benzothiophene S-oxides 1. Conditions: $1(0.2 \mathrm{mmol}), \mathrm{MeCN}(2.0 \mathrm{ml}), 0{ }^{\circ} \mathrm{C}$; TFAA $(0.4 \mathrm{mmol}) ; 5$ or 6 $(0.3 \mathrm{mmol}), 15 \mathrm{~min} ; 80^{\circ} \mathrm{C}, 3 \mathrm{~h}$ for allylation and $1 \mathrm{~h}$ for propargylation; Isolated yields. 
We next investigated the coupling of allyl (5) and propargyl silanes (6) with benzothiophene S-oxides 1 in the interrupted Pummerer/[3,3]-sigmatropic rearrangement/1,2-migration cascade for the synthesis of C2 alkylated benzothiophenes (Scheme 3). The allylation proceeded smoothly, even when the allyl silane bore reactive functional groups such as $\beta$-bromo (7c), $\beta$-chloromethyl (7d), and $\gamma$-ester (7e) substituents. Similarly, propargyl silanes $\mathbf{6}$ containing alkyl $(\mathbf{8 a}, \mathbf{b}, \mathbf{c}, \mathbf{d})$ and silyl $(\mathbf{8 e}, \mathbf{f})$ substituents at the terminal position underwent efficient metalfree cross coupling. In addition, a more challenging, hindered secondary propargyl silane delivered branched product $8 \mathbf{f}$ in $65 \%$ yield.

We propose that the metal-free $\mathrm{C} 2$ alkylation and arylation reactions follow common mechanistic steps (Scheme $5 \mathrm{~A}$ ). Electrophilic activation of the benzothiophene $S$-oxides 1 with TFAA forms sulfoxonium salts III. The coupling partner then engages III in an interrupted Pummerer reaction, were phenols (2) react through oxygen, ${ }^{[12,17]}$ and allyl $(5)^{[14 a, b, 18 b]}$ and propargyl (6) silane ${ }^{[14 c-e]}$ react though the $Y$-carbon in a $S_{E}^{\prime}$ fashion, to deliver sulfonium salts I. Sulfonium salts, analogous to I, have been formed and observed by NMR in the reaction of activated aryl sulfoxides with allyl and propargyl silanes. ${ }^{[14 b, c]}$ However, benzothiophenium salts I formed in the present study lack aromaticity $^{[30]}$ and undergo facile charge accelerated [3,3]sigmatropic rearrangement ${ }^{[16,20]}$ (at or below ambient temperature) and therefore were not observed. The [3,3]sigmatropic rearrangement delivery mechanism ensures that $\mathrm{C}$ $\mathrm{C}$ bond formation occurs in a completely site selective manner in terms of both the benzothiophene core and the coupling partner. Support for the interrupted Pummerer/[3,3]-sigmatropic rearrangement sequence is found in the regiospecificity of the reaction: only ortho substituted phenols are formed in the arylation, and allylated and propargylated products result from double $S_{E}$ '-type substitution. Indeed, regioisomeric para substituted phenols (9), and allylated and allenylated products (10) were not observed.

In the case of $\mathrm{C} 2$ arylation, C-C bond formation also occurs initially at $\mathrm{C} 3$, as shown by X-ray crystallographic analysis of thioacetal $3 \mathbf{a}$ (see Scheme 2A). Upon treating thioacetals $\mathbf{3}$ with $\mathrm{BF}_{3} \cdot \mathrm{OEt}_{2}$, we propose that the formed 3,3-disubstituted benzothiophenium II-A undergoes 1,2-migration of the coupling partner to C2. Similarly, with allyl and propargyl silanes, intermediate II-B undergoes 1,2-migration. As previously reported, when $\mathrm{R}=\mathrm{H}$ in II, rearomatisation occurs and $\mathrm{C} 3$ substituted benzothiophenes are formed. ${ }^{[21,31]}$

The 1,2-migration, that transfers the coupling partner from C3 to $C 2$, is a unique facet of the cascade. Literature precedent for this mechanistic pathway is scarce, ${ }^{[2]}$ which is likely due to the challenge of synthesizing 3,3-disubstituted benzothiopheniums and their precursors. We therefore sought experimental evidence to shed light on this key process by coupling C3-allyl (1b), and C3-Ph (1c) benzothiophene S-oxides with propargyl (6a) and allyl (5a) silanes (Scheme 5B). In the case of C3-allyl benzothiophene $S$-oxide $1 \mathrm{~b}$ and propargyl silane (6a), the major product $12 a$ is formed as a result of allyl migration along with minor product 11a arising from propargyl migration. Similarly, major product $\mathbf{1 2 b}$ was formed as a result of phenyl migration when $\mathrm{C} 3-\mathrm{Ph}$ benzothiophene S-oxide 1c was reacted with propargyl silane $\mathbf{6 a}$. When $\mathbf{1 c}$ and allyl silane $\mathbf{5 a}$ were reacted, phenyl (12c) and allyl (11c) migration occurred at similar rates. These results are inline with the hypothesis that 3,3-disubstituted benzothiophenium intermediates II are formed in the coupling process and that this is followed by 1,2-migration to effect $\mathrm{C} 2$ functionalization. Based on these observations and the results from Scheme 2, we are able to propose an order for migratory aptitudes in the metal-free $\mathrm{C} 2$ functionalization process to be: o-phenol>aryl allyl >propargyl>alkyl.

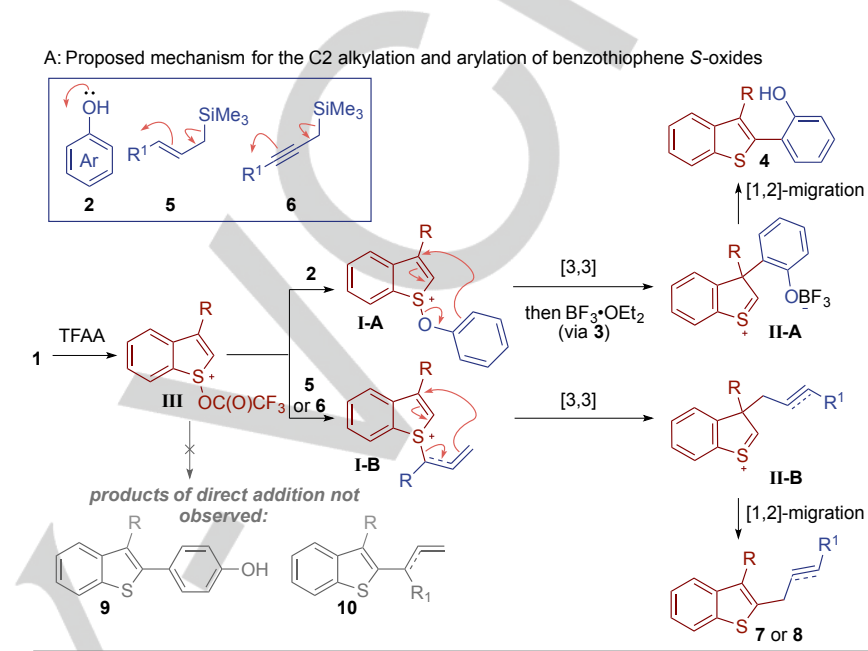

B: Mechanistic probe for the $\mathrm{C} 2$ alkylation and arylation
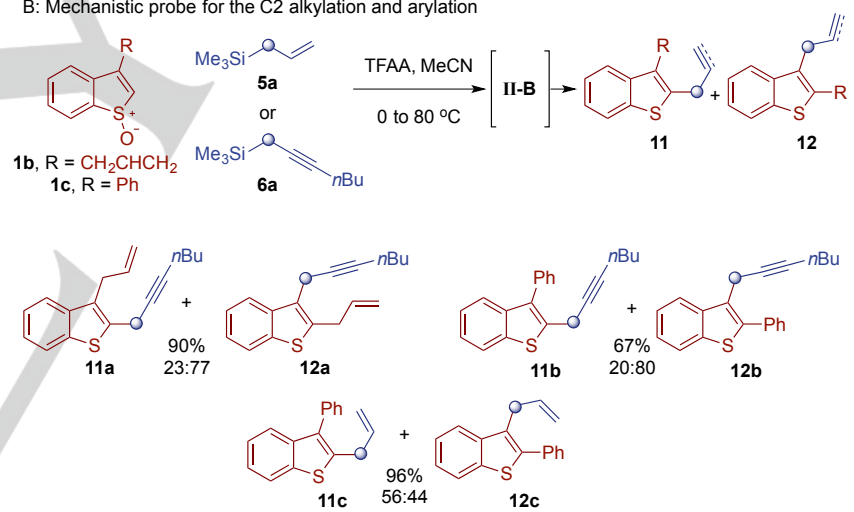

Scheme 5. Mechanistic hypothesis for the metal-free functionalization of benzothiophene $S$-oxides $(A)$ and mechanistic probes $(B)$.

We have begun to examine the synthetic utility of the products of metal-free C2 arylation (Scheme 6). In the field of organic electronics, benzothiophene ladder-type $p$-conjugated molecules such as benzothieno[3,2-b]benzothiophene (BTBT, see Scheme $1, X=S$ ) and derivatives are key components in organic lightemitting diodes (OLEDs), organic field effect transistors (OFETs), and photovoltaic cells. ${ }^{[3 a]}$ Replacing one sulfur atom in BTBT leads to benzothieno[3,2-b]benzofuran (BTBF) type materials that have interesting yet underexplored physical and chemical properties, such as luminescence and liquid crystallinity. ${ }^{[32]}$ Current synthetic strategies towards BTBF materials have high step counts or rely on transition metals. ${ }^{[33]}$ Given that metal contamination can adversely affect the performance of organic materials, ${ }^{[11]}$ a short, modular, transition metal-free route to BTBF materials is highly desirable. We therefore utilized a 
benzothiophene S-oxide bearing a C3 OMe substituent and phenol in the coupling to generate benzothiophene 4ad (Scheme 6A). Upon heating 4ad under acidic conditions, the phenolic oxygen displaced the C3 OMe group to generate BTBF in high yield. Unsymmetrical BTBT materials display more uniform crystallinity in thin films which results in enhanced mobility and increased thermal durability. ${ }^{[34]}$ The versatility of our metal free strategy was demonstrated in the modular synthesis of two novel BTBF analogues, Ph-BTBF-10 and 10-BTBF-Ph, whose structures are analogous to one of the best performing unsymmetrical BTBT materials. ${ }^{[34]}$

Finally, BTBF was readily oxidized to the corresponding $S$ oxide 13. Subsequent metal-free coupling with phenols gave unusual and novel heteropropellane type thioacetal structures, 14a-h (Scheme 6B).

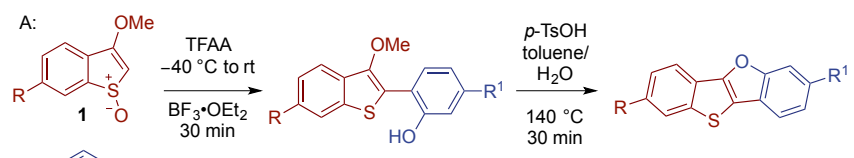

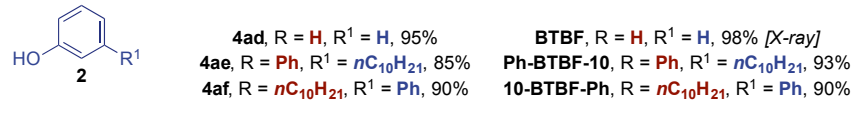

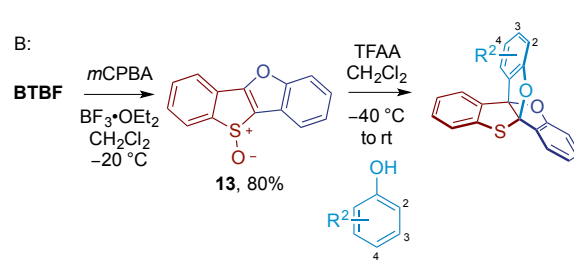

14a, $R^{2}=H, 99 \%$ $14 \mathrm{~b}, \mathrm{R}^{2}=4-\mathrm{NO}_{2}, 61 \%$ [X-ray] 14c, $R^{2}=4-\mathrm{Me}, 48 \%$ $14 \mathrm{c}, R^{2}=4-\mathrm{Me}, 48 \%$
$\mathrm{R}^{2}=4-\mathrm{Br}, 58 \%$ $14 \mathrm{e}, \mathrm{R}^{2}=4-\mathrm{CF}_{3}, 89 \%$ $14 f, R^{2}=4-C(0) P h, 71 \%$ $14 \mathrm{~g}, R^{2}=2-\mathrm{Br}, 48 \%$ $14 \mathrm{~h}, \mathrm{R}^{2}=3,5-(\mathrm{Me})_{2}, 92 \%$

Scheme 6. Transition metal-free synthesis of BTBF type materials (A) and heteropropellanes $14(\mathrm{~B})$.

We have described a metal-free, regioselective synthesis of $\mathrm{C} 2$ functionalized benzothiophenes. Synthetically underexplored benzothiophene $S$-oxides, prepared by simple oxidation of the corresponding benzothiophenes, serve as novel starting materials in coupling reactions with phenols, and allyl and propargyl silanes. The mechanism of both C2 alkylation and arylation processes operate via an interrupted Pummerer/[3,3]sigmatropic rearrangement/1,2 migration cascade. Due to the lack of aromaticity in the intermediate thiophene ring in benzothiophenium salts, the subsequent [3,3]-sigmatropic rearrangement is facile. In addition, this rearrangement ensures complete regioselectivity with respect to the benzothiophene core and the coupling partner. The 3,3-disubstituted benzothiophenium salts formed after [3,3]-sigmatropic rearrangement undergo a 1,2-migration to deliver $\mathrm{C} 2$ substituted benzothiophenes, a mechanistic pathway that has seldom been reported or employed in a synthetically useful manner. The facile $[3,3]$-sigmatropic rearrangement and 1,2-migration allows for mild conditions to be employed, which in turn allows the scope of the reaction to be broad and encompass a range of reactive functional groups in both coupling partners.

Given the prevalence of benzothiophenes in bioactive molecules and materials chemistry, we anticipate that these metal-free alkylation and arylation processes will be of broad utility.

\section{Acknowledgements}

We thank EPSRC (Postdoctoral Fellowships to Z.H. and J.A.F.S.; Established Career Fellowship to D.J.P.), The University of Manchester (Lectureship to A.P.P.; Studentship to H.J.S.), Novartis (Studentship to H.J.S.) Ministerio de Educación, Cultura y Deporte, Spain (Predoctoral FPU Fellowship to A.A.), and Erasmus+ (placement for J.N.) for their generous support.

Keywords: Sulfoxides - Pummerer reactions - Sulfur heterocycles $\cdot$ Sigmatropic rearrangement $\bullet$ Cascade reactions

[1] For a review of benzothiophenes found in biologically active molecules, see: R. S. Keri, K. Chand, S. Budagumpi, S. B. Somappa, S. A. Patil, B. M. Nagaraja, Eur. J. Med. Chem. 2017, 138, 1002.

[2] a) D. B. Muchmore, Oncologist 2000, 5, 388; b) S. A. Scott, C. T. Spencer, M. C. O'Reilly, K. A. Brown, R. L. Lavieri, C. H. Cho, D. I. Jung, R. C. Larock, H. A. Brown, C. W. Lindsley, ACS Chem. Biol. 2015, 10, 421; c) E. Pinto, M. R. P. Queiroz, L. A. Vale-Silva, J. F. Oliveira, A. Begouin, J.-M. Begouin, G. Kirsch, Bioorg. Med. Chem. 2008, 15, 2172; d) T. Banerjee, S.K. Sharma, N. Kapoor, V. Dwivedi, N. Surolia, A. Surolia, IUBMB Life 2011, 63, 1101; e) M. Sato, C. H. Turner, T. Wang, M. D. Adrian, E. Rowley, H. U. Bryant, J. Pharmacol. Exp. 1998, 287, 1; f) P. N. Munster, A. Buzdar, K. Dhingra, N. Enas, L. Ni, M. Major, A. Melemed, A. Seidman, D. Booser, R. Theriault, L. Norton, C. Hudis, J. Clin. Oncol. 2001, 19, 2002; g) E. von Angerer, S. Erber, J. Steroid Biochem. Mol. Biol. 1992, 41, 557; h) G. Naganagowda, P. Thamyongkit, R. Klai-U-dom, W. Ariyakriangkrai, A. Luechai, A. Petsom, J. Sulf. Chem. 2011, 32, 235.

[3] a) K. Takimiya, S. Shinamura, I. Osaka, E. Miyazaki, Adv. Mater. 2011, 23, 4347; b) K. Takimiya, I. Osaka, T. Mori, M. Nakano, Acc. Chem. Res. 2014, 47, 1493.

[4] a) I. Nakamura, T. Sato, Y. Yamamoto, Angew. Chem. Int. Ed. 2006, 45, 4473; b) B. Wu, N. Yoshikai, Org. Biomol. Chem. 2016, 14, 5402; c) A. S. Dudnik, V. Gevorgyan, In Catalyzed Carbon-Heteroatom Bond Formation (Ed.: A. K. Yudin), Wiley-VCH, 2011; d) C. M. Rayner, M. A. Graham, In Science of Synthesis: Benzo[b]thiophenes, Vol. 10 (Eds.: J. A. Joule, E. J. Thomas), 2001, pp 155.

[5] a) J. F. Hartwig, J. Am. Chem. Soc. 2016, 138, 2; b) T. Gensch, M. N. Hopkinson, F. Glorius, J. Wencel-Delord, Chem. Soc. Rev. 2016, 45, 2900; c) R. H. Crabtree, A. Lei, Chem. Rev. 2017, 117, 8481.

[6] For examples, see ref. $4 d$ and J. M. Hammann, D. Haas, P. Knochel, Angew. Chem. Int. Ed. 2015, 54, 4478.

[7] See ref. 4d and P. D. Clark, S. T. Mesher, Phosphorus Sulfur Silicon Relat. Elem. 1995, 105, 157.

[8] For selected examples, see: a) H. A. Chiong, O. Daugulis, Org. Lett. 2007, 9, 1499; b) B. Liégault, D. Lapointe, L. Caron, A. Vlassova, K. Fagnou, J. Org. Chem. 2009, 74, 1826; c) P. Hu, M. Zhang, X. Jie, W. Su, Angew. Chem. Int. Ed. 2012, 51, 227.

[9] a) I. Nakamura, A. I. Siriwardana, S. Saito, Y. Yamamoto, J. Org. Chem. 2002, 67, 3445; b) K. Mitsudo, P. Thansandote, T. Wilhelm, B. Mariampillai, M. Lautens, Org. Lett. 2006, 8, 3939; c) O. Vechorkin, V. Proust, X. Hu, Angew. Chem. Int. Ed. 2010, 49, 3061; d) C. S. Sevov, J. F. Hartwig, J. Am. Chem. Soc. 2013, 135, 2116; e) C. Theunissen, J. Wang, G. Evano, Chem. Sci. 2017, 8, 3465.

[10] European Medicines Agency. in $\mathrm{ICH}$ Guideline Q3D on Elemental Impurities (London, 2015) http://www.ema.europa.eu/docs/en_GB/document_library/Scientific_gui deline/2015/01/WC500180284.pdf. 
[11] Ö. Usluer, M. Abbas, G. Wantz, L. Vignau, L. Hirsch, E. Grana, C. Brochon, E. Cloutet, G. Hadziioannou, ACS Macro Lett. 2014, 3, 1134.

[12] T. Yanagi, S. Otsuka, Y. Kasuga, K. Fujimoto, K. Murakami, K. Nogi, H. Yorimitsu, A. Osuka, J. Am. Chem. Soc. 2016, 138, 14582.

[13] a) X. Huang, N. Maulide, J. Am. Chem. Soc. 2011, 133, 8510; b) X. Huang, M. Patil, C. Farés, W. Thiel, N. Maulide, J. Am. Chem. Soc. 2013, 135, 7312; c) B. Peng, D. Geerdink, C. Farés, N. Maulide, Angew. Chem. Int. Ed. 2014, 53, 5462; d) B. Peng, X. Huang, L. -G. Xie, N. Maulide, Angew. Chem. Int. Ed. 2014, 53, 8718; e) D. Kaiser, L. F. Veiros, N. Maulide, Chem. Eur. J. 2016, 22, 4727; f) D. Kaiser, L. F. Veiros, N. Maulide, Adv. Synth. Catal. 2017, 359, 64.

[14] a) A. J. Eberhart, C. Cicoira, D. J. Procter, Org. Lett. 2013, 15, 3994. b) A. J. Eberhart, J. E. Imbriglio, D. J. Procter, Org. Lett. 2011, 13, 5882 c) A. J. Eberhart, D. J. Procter, Angew. Chem. Int. Ed. 2013, 52, 4008 d) A. J. Eberhart, H. J. Shrives, E. Álvarez, A. Carrër, Y. Zhang, D. J. Procter, Chem. Eur. J. 2015, 21, 7428. e) A. J. Eberhart, H. Shrives, Y Zhang, A. Carrër, D. J. Tate, M. L. Turner, D. J. Procter, Chem. Sci. 2016, 7, 1281; f) J. A. Fernández-Salas, A. J. Eberhart, D. J. Procter, J. Am. Chem. Soc. 2016, 138, 790.

[15] a) L. Hu, Q. Gui, X. Chen, Z. Tan, G. Zhu, J. Org. Chem. 2016, 81, 4861; b) S. Akai, N. Kawashita, H. Satoh, Y. Wada, K. Kakiguchi, I. Kuriwaki, Y. Kita, Org. Lett. 2004, 6, 3793.

[16] For relevant reviews, see: a) A. P. Pulis, D. J. Procter, Angew. Chem. Int. Ed. 2016, 55, 9842; b) H. Yorimitsu, Chem. Rec. 2017, 17, 1156.

[17] For related reactions of other sulfoxides used in ortho $\mathrm{C}-\mathrm{H}$ arylation, see: a) T. Kobatake, D. Fujino, S. Yoshida, H. Yorimitsu, K. Oshima, J. Am. Chem. Soc. 2010, 132, 11838. b) K. Murakami, H. Yorimitsu, A Osuka, Angew. Chem., Int. Ed. 2014, 53, 7510.

[18] For other related reactions involving sulfonium intermediates, see: a) $\mathrm{T}$. Kobatake, S. Yoshida, H. Yorimitsu, K. Oshima, Angew. Chem. Int. Ed. 2010, 49, 2340; b) S. Yoshida, H. Yorimitsu, K. Oshima, Org. Lett. 2009 11, 2185; c) D. Chen, Q. Feng, Y. Yang, X. -M. Cai, F. Wang, S. Huang, Chem. Sci. 2017, 8, 1601. d) G. Hu, J. Xu, P. Li, Org. Lett. 2014 16, 6036. e) M. Tayu, K. Higuchi, T. Ishizaki, T. Kawasaki, Org. Lett. 2014, 16, 3613; f) J. A. Fernández-Salas, A. P. Pulis, D. J. Procter Chem. Commun. 2016, 52, 12364.

[19] L. H. S. Smith, S. C. Coote, H. F. Sneddon, D. J. Procter, Angew. Chem. Int. Ed. 2010, 49, 5832.

[20] X. Huang, S. Klimczyk, N. Maulide, Synthesis 2012, 44, 175.

[21] H. J. Shrives, J. Fernández-Salas, C. Hedtke, A. P. Pulis, D. J. Procter, Nature Commun. 2017, 8, 14801

[22] R. M. Acheson, J. K. Stubbs, J. Chem. Soc. Perkin Trans. 1, 1972, 0 , 899.

[23] a) J. Nakayama, Y. Sugihara, Sulfur Rep. 1997, 19, 349. b) T. Thiemann, H. Fujii, D. Ohira, K. Arima, Y. Lib, S. Mataka, New J. Chem. 2003, 27, 1377. c) T. Thiemann, K. Arima, K. Kumazoe S. Mataka, Rep. Inst. Adv. Mat. Study Kyushu Univ. 2000, 14, 139; d) M. E. F. E. Amoudi, P. Geneste, J. L. Olive, J. Org. Chem., 1981, 46, 4258; e) P.
Geneste, R. Durand, D. Pioch, Tetrahedron Lett. 1979, 4845; f) A. Bened, R. Durand, D. Pioch, P. Geneste, C. Guimon, G. P. Guillouze, J. -P. Declercq, G. Germain, P. Briard, J. Rambaud, R. Roques, J. Chem. Soc. Perkin Trans. // 1984, 1; g) E. David, J. Perrin, S. PelletRostaing, J. Fournier dit Chabert, M. Lemaire, J. Org. Chem. 2005, 70, 3569.

[24] P. Pouzet, I. Erdelmeier, P. M. Dansette, D. Mansuy, Tetrahedron 1998 , 54, 14811.

[25] Y. Li, T. Thiemann, T. Sawada, S. Mataka, M. Tashiro, J. Org. Chem 1997, 62, 7926.

[26] For seminal studies, see: a) A. H. Jackson, P. Smith, Chem. Commun. 1967, 265. For selected recent examples, see: b) Q. Nguyen, T. Nguyen, T. G. Driver, J. Am. Chem. Soc. 2013, 135, 620; c) P. LópezAlvarado, E. Caballero, C. Avendanõ, J. C. Menéndez, Org. Lett. 2006, 8, 4303.

[27] For isolated examples where 1,2-migration in 3,3-disubstitiuted benzothiopheniums might be occurring, see: a) R. Leardini, A. Tundo, G. Zanardi, Tetrahedron Lett. 1983, 24, 3381; b) K. Yong, M. Salim, A. Capretta, J. Org. Chem. 1998, 63, 9828.

[28] Conversion of $\mathbf{3 a}$ into $\mathbf{4 a}$ could also be accomplished with TFA or pTsOH and heating, but poorer conversions were observed.

[29] The X-ray crystallographic data for 3a, 4d, 4q', BTBF and 14b can be found at the Cambridge Crystallographic Data Centre (CCDC) under deposition numbers 1575954, 1575955, 1575956, 1575957 and 1577371, respectively.

[30] T. Kitamura, B. -X. Zhang, Y. Fujiwara, J. Org. Chem. 2003, 68, 731.

[31] When thioacetal $3(\mathrm{R}=\mathrm{H})$ is treated with $\mathrm{BF}_{3} \cdot \mathrm{OEt}_{2}$, mixtures of $\mathrm{C} 3$ and $\mathrm{C} 2$ arylated products are formed in 57:43 ratio respectively, as a result of competing aromatization and 1,2-migration in II-A, in a combined yield of $93 \%$.

[32] a) K. Černovská, J. Svoboda, I. Stibor, M. Glogarová, P. Vaněk, V. Novotná, Ferroelectrics 2000, 241, 231; b) J. -J. Aaron, C. Párkányi, A Adenier, C. Potin, Z. Zajíčková, O. R. Martínez, J. Svoboda, P. Pihera, P. Váchal, Fluoresc, J. 2011, 21, 2133; c) X. -K. Chen, L. -Y. Zou, A. M. Ren, J. -X. Fan, Phys. Chem. Chem. Phys. 2011, 13, 19490; d) Vektariene, A. J. Phys. Chem. A, 2013, 117, 8449.

[33] a) K. Černovská, M. Nič, P. Pihera, J. Svoboda, Collect. Czech. Chem. Commun. 2000, 65, 1939; b) H. Kaida, T. Satoh, K. Hirano, M. Miura, Chem. Lett. 2015, 44, 1125; (c) K. Saito, P. K. Chikkade, M. Kanai, Y Kuninobu, Chem. Eur. J. 2015, 21, 8365; d) M. Wang, J. Wei, Q. Fan, X. Jiang, Chem. Commun. 2017, 53, 2918; e) M. Matsumura, A Muranaka, R. Kurihara, M. Kanai, K. Yoshida, N. Kakusawa, D Hashizume, M. Uchiyama, S. Yasuike, Tetrahedron 2016, 72, 8085; (f) P. Pihera, H. Palecek, J. Svoboda, Collect. Czech. Chem. Commun. 1998, 63, 681; g) D. Chen, D. Yuan, C. Zhang, H. Wu, J. Zhang, B. Li, X. Zhu, J. Org. Chem. 2017, 82, 10920.

[34] H. lino, T. Usui, J. -i. Hanna, Nat. Commun., 2015, 6, 6828. 


\section{COMMUNICATION}

Benzothiophene S-oxides are transformed into $\mathrm{C} 2$ functionalized benzothiophenes in a cascade sequence involving an interrupted Pummerer, [3,3]-sigmatropic rearrangement, and an unexplored 1,2-migration. The reaction operates under metal-free conditions and delivers C2-arylated, -allylated and propargylated benzothiophenes.

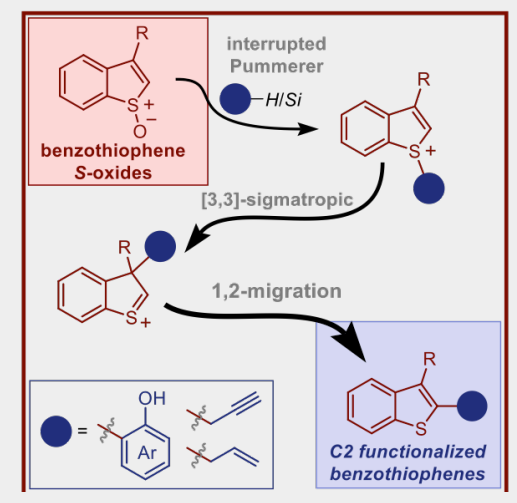

Zhen He, Harry J. Shrives, José A. Fernández-Salas, Alberto Abengózar, Jessica Neufeld, Kevin Yang, Alexander P. Pulis and David J. Procter*

Page No. - Page No.

Synthesis of C2 Substituted Benzothiophenes via an Interrupted Pummerer/[3,3]-Sigmatropic/1,2Migration Cascade of Benzothiophene S-Oxides 